\title{
Nanotechnology and Human Health: Scientific Evidence and Risk Governance
}

\author{
Martuzzi, Marco; Hansen, Steffen Foss; Howard, Vyvyan; Grieger, Khara
}

Publication date:

2012

Document Version

Publisher's PDF, also known as Version of record

Link back to DTU Orbit

Citation (APA):

Martuzzi, M., Hansen, S. F., Howard, V., \& Grieger, K. (2012). Nanotechnology and Human Health: Scientific Evidence and Risk Governance. Poster session presented at ISEE Conference 2012, Columbia, South Carolina, United States.

\section{General rights}

Copyright and moral rights for the publications made accessible in the public portal are retained by the authors and/or other copyright owners and it is a condition of accessing publications that users recognise and abide by the legal requirements associated with these rights.

- Users may download and print one copy of any publication from the public portal for the purpose of private study or research.

- You may not further distribute the material or use it for any profit-making activity or commercial gain

- You may freely distribute the URL identifying the publication in the public portal

If you believe that this document breaches copyright please contact us providing details, and we will remove access to the work immediately and investigate your claim 
P-244

\section{NANOTECHNOLOGY AND HUMAN HEALTH: SCIENTIFIC EVIDENCE AND RISK GOVERNANCE}

\section{Authors:}

Marco Martuzzi, World Health Organization - Regional Office for Europe, Germany, martuzzim@ecehbonn.euro.who.int

Steffen Foss Hansen, Technical University of Denmark, Denmark

Vyvyan Howard, University of Ulster, UK

Khara Grieger, RTI International, USA

Background and aims: Besides the promise of great benefits of nanotechnology, concerns exist on adverse health consequences. As complexity and uncertainty are large, evidence-based policy will be elusive, and models of risk governance are needed.

Methods: A critical assessment was conducted of key evidence on possible health implications of nanomaterials, with a view to identify options for risk governance and policy formulation.

Results: Current evidence is far from being conclusive. A cautionary approach in policy may be appropriate for several reasons: (i) humans have limited evolutionary experience of nanomaterials- a possible reason for the diminishing ability of cells to interact with particles at nanoscale level; (ii) nanoparticles can enter the body relatively easily, especially through inhalation and gastro-intestinal assimilation, and are very mobile once inside the body; (iii) several chemical-physical mechanisms resulting in cell damage have been reported; (iv) effects are often dependent on particle size, with a tendency to become more active as the particle size decreases; (v) population exposure to nanomaterials is not well known, but may be or become high, for example through cosmetics, food additives, or from airborne nanoparticles; (vi) potential adverse effects include a broad spectrum of adverse effects, specific and a-specific.

Conclusions: Assessing the risks of nanotechnology is challenging. One must take into account the unique complexities of the interaction with the human body. Innovative models and frameworks for risk assessment and risk governance are being developed and applied in order to inform policy.

Keywords: nanotechnology, nanoparticles, risk governance, health impact, emerging risks, uncertainty 